\title{
The Capability in Pronouncing the English Final Consonant Clusters by the English Department Students, Faculty of Humanities, Udayana University
}

\author{
Ni Luh Ketut Mas Indrawati ${ }^{1}$, Ida Ayu Made Puspani ${ }^{2}$ \\ ${ }^{1,2}$ Faculty of Humanities Udayana University, Bali Indonesia
}

\begin{abstract}
This study attempts to describe the ability of the English Department students, Faculty of Humanities, Udayana University in pronouncing English final consonant clusters. Consonant clusters are groups of consonants that can occur initially (onset) and finally (coda) in the syllable structure. The features of consonant clusters in each language are highly dependent on the language itself. In English, the number of consonants at the beginning of a syllable can be up to three such as: structure /str $\Lambda \mathrm{kt} \int \mathrm{\partial}$, spring /sprIn/, while the number of consonants that forms a cluster in the coda can be up to four as in sixths /siks $\mathbf{\theta s} /$, texts /teks $\theta \mathbf{s} /$. While, Consonant clusters in Indonesian and Balinese as the mother tongue of students are very limited in number and only exist initially in the words. This difference, obviously, creates problems for students in pronouncing English words containing these consonant clusters

The knowledge of the English sound system is taught in the English phonetic and phonemic course in the fifth semester at the English Department, Faculty of Humanities, Udayana University. This study examined the ability to pronounce consonant clusters by the second semester students who have not taken English Phonetic and Phonemic courses to be compared with students who have taken the course, so that it can be seen to what extent the course can change students' performance in pronouncing the consonant clusters.

This research is descriptive qualitative research, supported by quantitative data. The research population was 20 second semester students and 20 sixth semester students randomly taken. The research instrument was a list of English words containing consonant clusters and questionnaires. The data collection technique was done through recording, and the data were analyzed descriptive qualitatively and presented formally and informally.
\end{abstract}

KEYWORDS: Capability, Consonant Cluster, Pronunciation

\section{INTRODUCTION}

The English Department as a study program with AUNQ-A (Asian University Network Qualification Assessment) standard, has a high responsibility and task to improve the competence of its prospective graduates. English graduates are required to have good academic and non-academic abilities. Graduates of the English Department are targeted to be able to understand the English language system (grammar, phonology, morphology, semantics, syntax), comprehend learning principles, be proficient in using English to communicate orally or in writing. In addition, graduates are also able to conduct research in the Literature and English.

Experts argue that English pronunciation is one of the most difficult skills to acquire and learners should practice more to improve their pronunciation. Yates and Zielinski (2009) claim that pronunciation has a key role in learning English. Learners will not be able to pronounce English well, if they are not taught general rules and principles towards a comprehensive pronunciation i. Gilakjani (2012) states that acceptable pronunciation is one of the main requirements of learner competence. Ur (1996, in Handayani

2017:196) believes that indirect pronunciation exercises seem to be more helpful for young and beginners, where there is no direct teaching of pronunciation, no explanation, and no instruction. Direct exercises are appropriate for both adult and advanced learners, where the teacher teaches direct pronunciation, on the rules of pronunciation, explaining the places of articulation of different sounds, intonation patterns for different types of sentences. It was also stated that for learners of English as a second lan guage, the most difficult thing to master is to pronounce correctly.

The English Department offers English Phonetic and Phonemic course as one of the compulsory courses that is closely related to the English pronunciation. This course is given in the fifth semester and has 3 credits. The purpose of this course is to provide an understanding of the theoretical of English sound system, which can later be applied to improve English pronunciation 


\section{International Journal of Current Science Research and Review}

ISSN: 2581-8341

Volume 04 Issue 11 November 2021

DOI: 10.47191/ijesrr/V4-i11-05, Impact Factor: 5.825

IJCSRR@ 2021

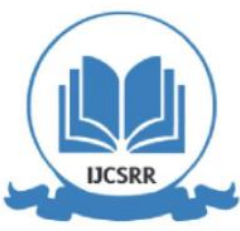

Www.ijesrr.org

in speaking skills.

Cook (1996 as quoted by Pourhosein Gilakjani, 2016) describes pronunciation as the production of English sounds. Pronunciation is learned through training the repetition of sounds and correcting them if the pronunciation is not correct. When learners start learning pronunciation they move on to new habits and overcome difficulties stemming from their mother tongue.

The pronunciation of English consonant clusters is generally a problem for students in the English Department, Faculty of Humanities, Udayana University, whose mother tongue is Balinese or Indonesian. This is caused by the differences in the English sound system and Balinese or Indonesian. English has 24 consonants while Indonesian has 18 and Balinese has 15. Dental consonants $/ \theta /$, / $/$, palato-alveolar consonants $/ \mathrm{J} /, / 3 /, / \mathrm{t} / / / \mathrm{d} z /$ do not exist in the learner's mother tongue. The combination of consonants in one cluster in English syllables varies widely. English has two to three consonants at the beginning of a syllable, and two up to four consonants at the end of a syllable. Meanwhile, Balinese and Indonesian do not have consonant clusters at the end of syllables. This is obviously a problem in the pronunciation of consonant clusters so that it requires more practices for the learners. This intrigued us to examine the ability of students of the English Department, Faculty of Humanities, Udayana University to pronounce English consonant clusters. Based on the background of the study there are two problems that are raised in this research, namely:1) How is the capability of the second and the sixth semester students in pronouncing the English final consonant clusters?

2) How is the effect of the English phonetic and phonemic course to thestudents in pronouncing the English consonants clusters?

\section{LITERARY REVIEW}

Vančová (2019) in the Journal of Language and Cultural Education, wrote an article entitled: Current Issues in Pronunciation Teaching to Non-Native Learners of English. He states that pronunciation plays an important role in communication, especially communication between native and non-native speakers. He argues that pronunciation teaching has shifted from accent-free or native-speaker-like pronunciation towards comprehensiveness and teaching exercises that are geared towards non-native English speakers, varying and often based on teacher opinion rather than research findings. Therefore, the purpose of this study is to present the current topic in 20 selected articles on pronunciation teaching. The findings are that teachers with good theoretical backgrounds can increase students' awareness of pronunciation and the phenomenon of overall pronunciation performance both at the segmental and suprasegmental levels. Students may benefit from strategies applied to pronunciation learning, but traditional teaching methods are still dominant in contemporary English classes.

Gilakjani (2016) in the International Journal of Research in English Education published an article on the topic English Pronunciation Instruction: A Literature Review. He exposed that the problem of English pronunciation instruction was caused by several reasons such as: the absence of clear guidelines for teachers so that teachers were faced with conflicting exercises regarding pronunciation instructions and the unavailability of a systematic method for determining what to teach, when, and how to do it so that teachers don't feel comfortable when teaching pronunciation in class. In his article he reviews several important issues regarding pronunciation instruction with the aim of defining pronunciation terms, examines the purpose of pronunciation instruction, explains the importance of pronunciation instruction, explains the teacher's role in teaching pronunciation and provides some ideas in helping teachers improve learner's pronunciation. This literature review shows that if teachers want to teach pronunciation accurately, they must be trained in pronunciation instructions.

Nafisah Endahati (2014) researched the Improvement of Pronunciation Ability of Class A1 Students in Semester I of the English Education Study Program FKIP UPY FY 2013/2014 through an Audiolingual Approach by applying collaborative and participatory classroom action research methods. The results of his research show that the audiolingual approach with pronunciation practice techniques in learning can improve pronunciation skills in English. This can be indicated by the increasing accuracy of student pronunciation in all aspects of sounds in English, emphasis on syllables in vocabulary, and intonation in sentences. The improvement of speaking skills in English class is also supported by the results of the absorption of understanding on pronunciation skills in English with a percentage value of $63.33 \%$ (cycle I), $73.33 \%$ (cycle II), and $80 \%$ (cycle III). .

Roach (1983:68) defines consonant clusters as two or more consonants in a group or cluster, which occupy the onset (consonant at the beginning) or coda (consonant at the end) in the syllable structure. Syllables are described as consisting of a core (centre) filled with vowels so that it sounds louder than the onset or coda filled with consonants. The syllable structure is described as follows. 


\section{International Journal of Current Science Research and Review}

ISSN: 2581-8341

Volume 04 Issue 11 November 2021

DOI: 10.47191/ijcsrr/V4-i11-05, Impact Factor: 5.825

IJCSRR@ 2021

www.ijesrr.org

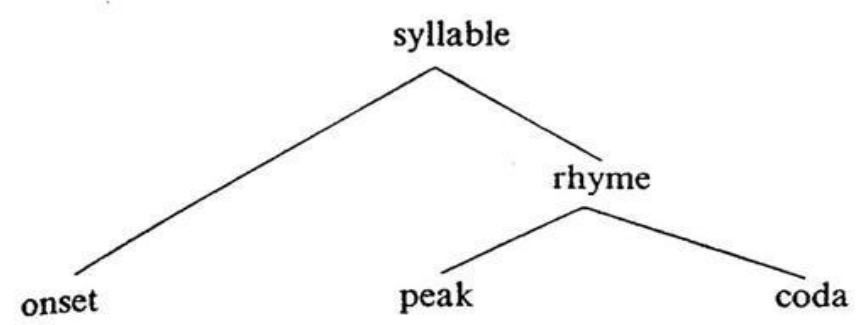

In English, syllables can be without onset or coda as in: are /a:/ and or /D:/ this is called minimum syllable. Syllables can also be without coda as in no/nөv/, to /tu:/, or without onset as in on /mn/, in /In/, and can also be complete with onset and coda as in but / $\mathrm{b} \Lambda \mathrm{t} / \mathrm{cut} / \mathrm{k} \Lambda \mathrm{t} /$. Onset can contain more than one consonant as in the words try, speak, play/traI, spi:k, pleI/, and can also consist of three consonants as in the words: string, spring, splash /strIy, sprIn, splæ $/$. Meanwhile, coda can be filled with up to four consonants

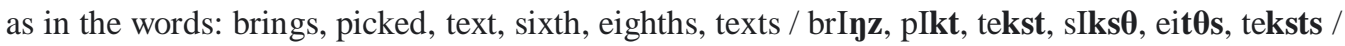

Seeing that the final consonant cluster that occupies the coda can be up to four consonants while Balinese or Indonesian language does not have consonant clusters in the coda, this is obviously problematic for students of the English Department, Faculty of Humanities, Udayana University.

\section{RESEARCH METHODS}

This research is classified as a descriptive -qualitative research. The data were qualitative in nature supported by quantitative data. The population of this research was the second semester students and students from the sixth semester in the English Department, Faculty of Humanities, Udayana University. 20 second semester students and 20 sixth semester students were randomly taken as the samples of this research. Most of the respondents speak Indonesian and some speak Balinese as their mother tongues. The data were taken from the results of the recording of the pronunciation of 45 English words containing three different categories of consonant clusters, they are category one that contain two consonants in a cluster, category two consisting of three consonants in a cluster, and category three that contains four consonants in a cluster, and the results of the questionnaires distributed to 40 respondents from both groups. The data that had been collected were presented in the form of tables and graph and were analyzed in a descriptive-qualitative manner based on the phonological theory by Roach (1983).

\section{RESULTS AND DISCUSSION}

4.1 The Capability of the Second Semester Students of the English Department, Faculty of Humanities, Udayana University in the Pronunciation of the English Final Consonant Clusters.

The recording results of the pronunciation of 45 English words containing consonant clusters by 20 second semester students were listened to and phonemically transcribed to determine which words contained consonant clusters, which were still problematic for the students. The results of listening to the pronunciation of the three groups of consonants in English can be described as follows.

Of the 45 English words tested to 20 second semester students (10 female and 10 male students), the student achievement ranged from the lowest score of 51 and the highest of 82, and the average student achievement in pronouncing the final consonant cluster as a whole was 72.90 . The male student achievement in this semester is higher than the female ones, which is around 67 and 82 , and the average student achievement in pronouncing the final consonant cluster as a whole is 74.80. The achievement range of the female students in this semester is the same as the range of student achievement as the whole, from 51 up to 82 , while the average achievement is 72.90 for more details the overall pronunciation achievement can be described as in the following table. 


\section{International Journal of Current Science Research and Review}

ISSN: 2581-8341

Volume 04 Issue 11 November 2021

DOI: 10.47191/ijcsrr/V4-i11-05, Impact Factor: 5.825

IJCSRR@ 2021

www.ijesrr.org

Table 1. The score of the ability in pronouncing the English final consonant clusters by the second semester students.

\begin{tabular}{|c|c|c|c|c|c|}
\hline $\begin{array}{l}\text { Female students. } \\
\text { NO. }\end{array}$ & $\begin{array}{l}\text { Number } \\
\text { correct }\end{array}$ & score & $\begin{array}{l}\text { Male students. } \\
\text { NO. }\end{array}$ & $\begin{array}{ll}\begin{array}{l}\text { Number } \\
\text { correct }\end{array} & \text { of }\end{array}$ & score \\
\hline 1 & 30 & 67 & 11 & 36 & 80 \\
\hline 2 & 31 & 69 & 12 & 36 & 80 \\
\hline 3 & 34 & 75 & 13 & 30 & 67 \\
\hline 4 & 37 & 82 & 14 & 36 & 80 \\
\hline 5 & 32 & 71 & 15 & 31 & 69 \\
\hline 6 & 31 & 69 & 16 & 31 & 69 \\
\hline 7 & 23 & 51 & 17 & 34 & 75 \\
\hline 8 & 34 & 75 & 18 & 32 & 71 \\
\hline 9 & 35 & 78 & 19 & 34 & 75 \\
\hline 10 & 33 & 73 & 20 & 37 & 82 \\
\hline \multirow{2}{*}{\multicolumn{2}{|c|}{ RERATA }} & \multicolumn{2}{|l|}{$710: 10=\mathbf{7 1}$} & \multicolumn{2}{|l|}{$748 ; 10=\mathbf{7 4 . 8 0}$} \\
\hline & & $\frac{71+74.80}{2}=$ & & & \\
\hline
\end{tabular}

The score in table 1 above was obtained from the number of correct pronunciations divided by the number of words containing the final consonant clusters tested, multiplied by one hundred percent. The ability to pronounce the final consonant clusters by the second semester students (the mean is 72.90) can be categorized as quite high. This is supported by the results of the questionnaire results from students' English UAN (National final Examination), as respondents in this study, 17 students (85\%) obtained UAN above 8 and only $15 \%$ were below 8 . When viewed from the high schools where they came from, most $(65 \%)$ of them are from state high schools. This shows that their English proficiency in general can be said to be quite good.

\subsection{Distribution of final consonant cluster pronunciation errors by the second semester students}

Pronunciation problems for the 20 students in the second semester are found in the final consonant cluster of group 3, namely a group consisting of 4 consonants. Student achievement is very low at only $0 \%$ while for female students it is only $4 \%$ so that the average for the two groups in this semester is only $2 \%$. This is not surprising because the range of sounds that must be pronounced is very large compared to that in the student's mother tongue.

There are $14(65 \%)$ of the 20 words containing the final consonant cluster in the consonant cluster group 1, which were difficult to be pronounced by the 10 female students in this this semester. Of the 14 words the most difficult to pronounce is the consonant cluster /-ðz/ as in the word clothes /kləəðz/, 9 students still have problems uttering it, they tend to replace the consonant /-ð/ with /$\mathrm{d} /$ and $/-\mathrm{z} /$ with $/ \mathrm{-s} /$. As for male students, there are $6(45 \%)$ of the 20 words containing the final consonant in group 1 , which were still difficult for them, and the most difficult one is the consonant cluster /-st/, as in the word twist /twist/, trust /tr $\Lambda$ st/ they tend not to pronounce the consonant $/-\mathrm{t} /$ in the cluster.

For the final consonant cluster, group 2 (a group consisting of 3 consonants), 14 (65\%) of the 20 words containing the final consonant clusters which were difficult for female students to pronounce. The consonant cluster that was the most difficult they pronounced was /-sts/, 7 out of 10 female students in the second semester could not pronounce the final consonant cluster in the word crafts / kra:fts / and twists /twists/ correctly, their pronunciation only reaches the first or first and second consonants, some students miss the pronunciation of the second consonant. As for male students, there were $16(80 \%)$ consonant clusters that were still difficult to pronounce. Of the 16 words containing the 3 final consonants, as well as female students, students in this semester also experienced problems in pronouncing of words containing the final consonant cluster/-sts/, the ten students in this semester could not pronounce the word twists /twists/ Correctly.

The third group of final consonants is the most difficult for both male and female students, of the ten female students involved in this study, only one can pronounce correctly one word from this group, namely the word sixths /ssks $\theta$ s/, while all of them experienced difficulty in pronouncing the words containing consonant clusters in this group. The distribution of final consonant cluster 
International Journal of Current Science Research and Review

ISSN: 2581-8341

Volume 04 Issue 11 November 2021

DOI: 10.47191/ijcsrr/V4-i11-05, Impact Factor: 5.825

IJCSRR @ 2021

www.ijicsrr.org

pronunciation by the second semester students can be observed in table 2 below.

Table 2. The distribution of the English final consonant cluster pronunciation by the second semester students.

\begin{tabular}{|c|c|c|c|c|c|c|}
\hline \multirow{3}{*}{$\begin{array}{l}\mathbf{N} \\
\mathbf{O} \\
1 .\end{array}$} & \multirow{2}{*}{\multicolumn{2}{|c|}{$\begin{array}{l}\text { Words containing the } \\
\text { English final cons. cluster }\end{array}$}} & \multicolumn{2}{|c|}{ Male students } & \multicolumn{2}{|c|}{ Female students } \\
\hline & & & Incorrect. \% & Correct. \% & Incorrect. \% & Correct. \% \\
\hline & Storms & sto:mz & - & 100 & 30 & 70 \\
\hline 2. & Clothes & kləひðz & - & 100 & 90 & 10 \\
\hline 3. & Stops & stpps & - & 100 & 10 & 90 \\
\hline 4. & Stars & starz & - & 100 & - & 100 \\
\hline 5. & Smiled & smaild & - & 100 & - & 100 \\
\hline 6. & Clank & klæyk & 30 & 70 & - & 100 \\
\hline 7. & Branch & bra:ntf & - & 100 & 70 & 30 \\
\hline 8. & Print & print & 20 & 80 & 20 & 80 \\
\hline 9. & Milk & milk & - & 100 & 10 & 90 \\
\hline 10 & Craft & kra:ft & - & 100 & 80 & 20 \\
\hline 11 & Clouds & klavdz & 10 & 90 & 10 & 90 \\
\hline 12 & Snitch & snittf & - & 100 & 10 & 90 \\
\hline 13 & Flounce & flaons & - & 100 & 40 & 60 \\
\hline 14 & Trust & $\operatorname{tr} \Lambda \mathbf{S t}$ & 60 & 40 & 20 & 80 \\
\hline 15 & Twist & twist & 60 & 40 & 10 & 90 \\
\hline 16 & Ground & graond & 30 & 70 & 40 & 60 \\
\hline 17 & Plump & plımp & - & 100 & 20 & 80 \\
\hline 18 & Smelt & smelt & - & 100 & - & 100 \\
\hline 19 & Help & help & - & 100 & - & 100 \\
\hline 20 & Bulb & $\mathrm{b} \Lambda \mathbf{l b}$ & - & 100 & - & 100 \\
\hline 21 & Stamps & stæmps & 10 & 90 & 20 & 80 \\
\hline 22 & Strengths & $\operatorname{str} \varepsilon \eta \theta s$ & 10 & 90 & 20 & 80 \\
\hline 23 & Blends & blendz & - & 100 & 10 & 90 \\
\hline 24 & Prints & prints & 30 & 70 & - & 100 \\
\hline 25 & Twists & twISts & 100 & - & 70 & 30 \\
\hline 26 & Prompt & prompt & 60 & 40 & 10 & 90 \\
\hline 27 & Twelfth & twelff $\theta$ & 30 & 70 & 20 & 80 \\
\hline 28 & Scripts & skrıpts & 20 & 80 & 10 & 90 \\
\hline 29 & Plumps & $\mathrm{pl} \Lambda \mathbf{m p s}$ & 10 & 90 & - & 100 \\
\hline 30 & Cramped & kræmpt & 30 & 70 & 10 & 90 \\
\hline 31 & Pinched & pintft & 510- & 100 & - & 100 \\
\hline 32 & Shrimps & frimps & $620-$ & 100 & 30 & 70 \\
\hline 33 & Scripts & skrıpts & 10 & 90 & 30 & 70 \\
\hline 34 & Crafts & kra:fts & 20 & 80 & 70 & 30 \\
\hline 35 & Cramped & kræmpt & 30 & 70 & 40 & 60 \\
\hline 36 & Spends & spendz & - & 100 & - & 100 \\
\hline 37 & Prompt & prompt & 20 & 80 & 10 & 90 \\
\hline 38 & Lamps & læmps & 20 & 80 & 20 & 80 \\
\hline 39 & Links & ligks & 10 & 90 & - & 100 \\
\hline
\end{tabular}




\section{International Journal of Current Science Research and Review}

ISSN: 2581-8341

Volume 04 Issue 11 November 2021

DOI: 10.47191/ijcsrr/V4-i11-05, Impact Factor: 5.825

IJCSRR@ 2021

www.ijcsrr.org

\begin{tabular}{|c|c|c|c|c|c|c|}
\hline 40 & Belts & belts & 10 & 90 & - & 100 \\
\hline 41 & Texts & teksts & 100 & - & 100 & - \\
\hline 42 & Sixths & siks $\theta$ s & 100 & - & 90 & 10 \\
\hline 43 & Twelfths & twelf $\theta \mathbf{s}$ & 100 & - & 100 & - \\
\hline 44 & Prompts & prompts & 100 & - & 100 & - \\
\hline 45 & Tempts & tempts & 100 & - & 90 & 10 \\
\hline
\end{tabular}

4.3 The Capability of the Sixth Semester Students of the English Department, Faculty of Humanities, Udayana University, in Pronouncing the English final consonant clusters

After listening to the recording results of the 45 English words containing the final consonant clusters by the sixth semester students, then the phonemic transcriptions were done to determine which consonant clusters, are problematic for the students. The results of listening to the pronunciation of the English final consonant clusters, the scores can be presented in table 3 below.

Table 3. The scores of the students' capability in pronouncing the English final consonant.

\begin{tabular}{|c|c|c|c|c|c|}
\hline $\begin{array}{l}\text { Students } \\
\text { 'number }\end{array}$ & $\begin{array}{c}\text { The total of } \\
\text { correct. answer }\end{array}$ & score & $\begin{array}{l}\text { Students } \\
\text { 'number }\end{array}$ & $\begin{array}{l}\text { The total of } \\
\text { correct. }\end{array}$ & Score \\
\hline 1 & 36 & 80 & 11 & 33 & 73 \\
\hline 2 & 39 & 87 & 12 & 36 & 80 \\
\hline 3 & 37 & 82 & 13 & 40 & 89 \\
\hline 4 & 35 & 78 & 14 & 39 & 87 \\
\hline 5 & 38 & 84 & 15 & 36 & 80 \\
\hline 6 & 34 & 75 & 16 & 33 & 73 \\
\hline 7 & 38 & 84 & 17 & 35 & 78 \\
\hline 8 & 36 & 80 & 18 & 36 & 80 \\
\hline 9 & 37 & 82 & 19 & 38 & 84 \\
\hline 10 & 37 & 82 & 20 & 35 & 78 \\
\hline \multicolumn{2}{|c|}{ Total $=$} & \multicolumn{2}{|c|}{$\begin{array}{l}814 \\
814: 10=81.40\end{array}$} & \multicolumn{2}{|c|}{$\begin{array}{r}802 \\
802: 10=80.20\end{array}$} \\
\hline \multicolumn{2}{|c|}{ Average score } & \multicolumn{2}{|c|}{$\frac{81.40+80.20}{2}=80.80$} & & \\
\hline
\end{tabular}

Table 3 shows that of the 45 English words tested to 20 students (10 female and 10 male students), in the sixth semester, female students' achievements ranged from the lowest of 75 and the highest of 84 and the average student achievement in pronunciation of the final consonant cluster as a whole was 81.40. Meanwhile, the male student achievement in this semester is smaller than the female ones, which were around 73 and 84 , and the average student achievement in pronouncing the final consonant cluster as a whole is 80.80 . The range of achievement in the pronunciation of consonant clusters by the 20 sixth semester students is the same as the range of male student achievement, which ranges from 73 and 89 , while the average achievement is 80.80 for more details the overall pronunciation achievement can be described as in table 4 .

The ability to pronounce final consonant clusters by the sixth semester students with an average of 80.80 can be categorized as high. This is supported by the results of the questionnaire on students' English UAN (National Exam) achievements, 13 students (65\%) obtained English score in the UAN above 8 (80\%) and 35\% below 8 and above 5 . When viewed from the high school where they graduated, most $(75 \%)$ of them were from state high schools. When viewed from the background of UAN (National Exam) score for English and their school of origin, their English proficiency in general could be considered high. They had also been taught English consonant clusters through the English Phonetics \& Phonemics course in the English Department. One of the topics in this course is the structure of the English syllables, which contains how many consonants can be in a cluster at the beginning and end of a syllable in English. According to the results of the questionnaire asked, whether the English Phonetics \& Phonemics course helped students improve their ability to pronounce English words, 12 (60\%) agreed absolutely, 7 (35\%) agreed, and only 1 


\section{International Journal of Current Science Research and Review}

ISSN: 2581-8341

Volume 04 Issue 11 November 2021

DOI: 10.47191/ijcsrr/V4-i11-05, Impact Factor: 5.825

IJCSRR@ 2021

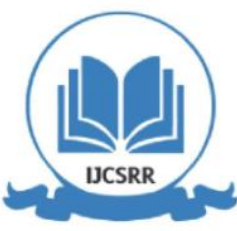

Www.ijesrr.org

(5\%) disagreed Pronunciation problems for the 20 students in the sixth semester were found in the final consonant cluster in group 3. Student achievement is very low at only $38 \%$ for male students, while for female students it was only $20 \%$ so that the average for the two groups in this semester was only $29 \%$. The range of sounds that must be pronounced was very high compared to that in the students' mother tongue, even though they understood the theory but in applying it, they still have problems due to the difficulty in pronouncing the four consonants in the coda. Of the 20 words containing the final consonant cluster in the consonant cluster group1, there were 10 words that were still difficult for the 10 female students in the sixth semester. Of the 10 words that were the most difficult to pronounce, 4 students had problems in pronouncing the consonant clusters /-ðz/, /-ft/, /-st/ in Clothes/ kləuðz/, Craft/ kra:ft/, and Twist /twist/. Then followed by the consonant cluster/-mz/ as in the word storms / sto:mz/, 3 female students mispronounced it, and the consonant cluster/-nd/ in the word ground / graond/ there were 2 female students who pronounced it incorrectly, and the consonant cluster /-lb/ in the word bulb /bslb/ there was 1 student who mispronounced it.

Meanwhile, for the male students, the final consonant cluster pronunciation errors in group 1 were the final consonant cluster /-dz/ in the words clothes /kləøðz/, and /-st/ in the word trust / tr $\Lambda$ st/, by 4 students, while in the word twist / twist /there were 3 students, followed by the final consonant cluster /-nd/ 2 students, and /-nk/ in the word Clank/klæ $\mathrm{kk} /$ there was 1 student.

For the final consonant cluster, group 2 (a group consisting of 3 consonants), 12 words that contain final consonant clusters that were still difficult for female students. The most difficult consonant cluster to pronounce was /-sts/; 7 out of 10 students in the sixth semester could not pronounce the final consonant cluster in the word twists / twists /, for /-fts/ in the word crafts / kra:fts / there were 3 students who had wrong pronunciation, and for /-mpt/ and /-mps/ in the word prompt / prompt / promps / promps/

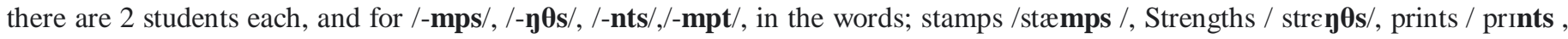
plumps / plımps/, cramped /kræmpt/, and lamps / læmps/ 1 student each.

For male students, there were 14 pronunciation errors in the final consonant cluster, group 2, namely; /- mps/, /-nӨs/, /-sts/, /-mpt/, /-pts/, /-mps/, /-mpt/, /-ndz/, /-nks/, and /-lts/. There were 5 students who mispronounced the words stamps / stæmps/ and lamps / læmps/ 4 students mispronounced the words cramped /kræmpt/ and crafts / kra:fts/, 3 students mispronounced the words scripts / skrıpts/, plumps / plımps/, twists /twists /, scripts / skrıpts/ and stripts /stripts/. There were 2 students who mispronounced the words shrimps / $\mathrm{rimps} /$, cramped / kræmpt/, and promps / promps/ and 1 student had incorrect pronunciation in the words strengths

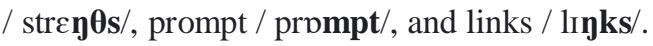

The distribution of the pronunciation of the final consonant cluster by the sixth semester students can be observed in table 4 below

Table 4. Distribution of final consonant cluster pronunciation by sixth semester students

\begin{tabular}{|c|c|c|c|c|c|c|}
\hline \multirow{3}{*}{$\begin{array}{c}\text { NO } \\
1 .\end{array}$} & \multirow{2}{*}{\multicolumn{2}{|c|}{$\begin{array}{l}\text { Words containing the } \\
\text { English final cons. cluster }\end{array}$}} & \multicolumn{2}{|c|}{ Male students } & \multicolumn{2}{|c|}{ Female students } \\
\hline & & & \multirow{2}{*}{$\frac{\text { incorrect \% }}{-}$} & \multirow{2}{*}{$\begin{array}{c}\text { Correct. \% } \\
100\end{array}$} & \multirow{2}{*}{$\frac{\text { Incorrect. } \%}{30}$} & \multirow{2}{*}{$\begin{array}{c}\text { Correct. \% } \\
70\end{array}$} \\
\hline & Storms & sto:mz & & & & \\
\hline 2. & Clothes & kləฮðz & 40 & 60 & 40 & 60 \\
\hline 3. & Stops & stpps & - & 100 & - & 100 \\
\hline 4. & Stars & starz & - & 100 & - & 100 \\
\hline 5. & Smiled & smaild & - & 100 & - & 100 \\
\hline 6. & Clank & klæりk & 10 & 90 & 10 & 90 \\
\hline 7. & Branch & bra:ntf & - & 100 & - & 100 \\
\hline 8. & Print & print & - & 100 & 10 & 90 \\
\hline 9. & Milk & milk & - & 100 & - & 100 \\
\hline 10. & Craft & kra:ft & - & 100 & 40 & 60 \\
\hline 11. & Clouds & klavdz & - & 100 & - & 100 \\
\hline 12. & Snitch & snittf & - & 100 & - & 100 \\
\hline 13. & Flounce & flaons & - & 100 & - & 100 \\
\hline
\end{tabular}




\section{International Journal of Current Science Research and Review}

ISSN: 2581-8341

Volume 04 Issue 11 November 2021

DOI: 10.47191/ijesrr/V4-i11-05, Impact Factor: 5.825

IJCSRR@ 2021

www.ijesrr.org

\begin{tabular}{|c|c|c|c|c|c|c|}
\hline 14 & Trust & $\operatorname{tr} \Lambda \mathbf{s t}$ & 30 & 70 & 20 & 80 \\
\hline 15 & Twist & twISt & 40 & 60 & 40 & 60 \\
\hline 16 & Ground & graond & 20 & 80 & 10 & 90 \\
\hline 17 & Plump & $\mathrm{pl} \wedge \mathbf{m p}$ & - & 100 & - & 100 \\
\hline 18 & Smelt & smelt & - & 100 & - & 100 \\
\hline 19 & Help & help & - & 100 & - & 100 \\
\hline 20 & Bulb & $\mathrm{b} \Lambda \mathrm{lb}$ & - & 100 & 10 & 90 \\
\hline 21 & Stamps & stæmps & 50 & 50 & 10 & 90 \\
\hline 22 & Strengths & $\operatorname{str\varepsilon \eta \theta s}$ & 10 & 90 & 10 & 90 \\
\hline 23 & Blends & blendz & - & 100 & - & 100 \\
\hline 24 & Prints & prints & - & 100 & 10 & 90 \\
\hline 25 & Twists & twists & 30 & 70 & 70 & 30 \\
\hline 26 & Prompt & prompt & 10 & 90 & 20 & 80 \\
\hline 27 & Twelfth & twelff $\theta$ & - & 100 & - & 100 \\
\hline 28 & Scripts & skrıpts & 30 & 70 & - & 100 \\
\hline 29 & Plumps & $\mathrm{pl} \Lambda \mathrm{mps}$ & 30 & 70 & 10 & 90 \\
\hline 30 & Cramped & kræmpt & 40 & 60 & 10 & 90 \\
\hline 31 & Pinched & pintft & - & 100 & - & 100 \\
\hline 32 & Shrimps & frimps & 20 & 80 & 20 & 80 \\
\hline 33 & Scripts & skripts & 30 & 70 & 10 & 90 \\
\hline 34 & Crafts & kra:fts & 40 & 60 & 30 & 70 \\
\hline 35 & Cramped & kræmpt & 20 & 80 & - & 100 \\
\hline 36 & Spends & spendz & - & 100 & - & 100 \\
\hline 37 & Prompt & prompt & 20 & 80 & 20 & 80 \\
\hline 38 & Lamps & læmps & 50 & 50 & 10 & 90 \\
\hline 39 & Links & links & 10 & 90 & - & 100 \\
\hline 40 & Belts & belts & - & 100 & - & 100 \\
\hline 41 & Texts & teksts & 70 & 30 & 90 & 10 \\
\hline 42 & Sixths & siks $\theta$ s & 70 & 30 & - & 100 \\
\hline 43 & Twelfths & twelf $\boldsymbol{\theta} \mathbf{s}$ & 30 & 70 & 40 & 60 \\
\hline 44 & Prompts & prompts & 70 & 30 & 90 & 10 \\
\hline 45 & Tempts & tempts & 70 & 30 & 80 & 20 \\
\hline
\end{tabular}

\subsection{The Role of English Phonetics and Phonemics Course in Pronunciation Ability}

The English phonetics and phonemics course is a compulsory subject given in the fifth semester in the English Department. The purpose of this course is to improve students' English pronunciation in speaking skills by applying English sound theory which includes: vowel sounds, diphthongs, consonants, consonant clusters, syllables, stress patterns and intonation. English consonant clusters are one of the subjects in this course. This topic is given after students are introduced to the understanding of language sounds which are distinguished into vowels and consonants. Then proceed to the introduction of single vowel sounds in English which are divided into short vowels and long vowels, so that the number of single vowels in English is much larger than the number of single vowels in Indonesian and Balinese as the students' mother tongue. The difference in the number of single vowels possessed by English as the language studied, with Indonesian and Balinese as the mother tongue is very large, which of course requires more effort from students to be able to master it. Short vowels such as /I/, /e/, /o/, / //, /o/, / / and long vowels: /i:/, /u:/, / $: /, / a: /, / 3: /$ are phonemes in English so mispronunciation can lead to misunderstandings in communication. Similarly, the number of consonants in English is much higher than the number of consonants in Indonesian and Balinese as mother tongues, obviously it needs more effort for students to master it. The English consonants not found in Indonesian and Balinese include: dental fricative $/ \theta /$, /ð/, palatal fricative sound $/ \mathrm{J} /, / 3 /$, palatal affricates $/ \mathfrak{t} /, / \mathrm{d}_{3} /$. It requires more Practice to be able to pronounce them correctly. 


\section{International Journal of Current Science Research and Review}

ISSN: 2581-8341

Volume 04 Issue 11 November 2021

DOI: 10.47191/ijcsrr/V4-i11-05, Impact Factor: 5.825

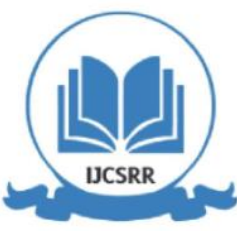

www.ijesrr.org

The number of consonants in English is 24, and these 24 consonants can form a cluster called a consonant cluster. Consonant clusters can appear at the beginning of words or at the end of words in English, at the end of words the consonant cluster can consist of two, three, and four consonants, while Indonesian and Balinese only have consonant clusters at the beginning of words. Of course, this is a challenge for lecturers in English phonetics and phonemics in order to achieve the teaching objectives.

The average score of consonant cluster pronunciation by the second and sixth semester students shows a significant difference, namely; 72.90 (for the second semester) and 80.80 (for the sixth semester) indicating that English phonetics and phonemics have a significant role in increasing student achievement in the pronunciation of the English final consonant clusters. This is further strengthened by the results of the questionnaire from respondents, namely, 14 (70\%) of them said that the English Phonetics and Phonemics course provided enough practice to pronounce consonant clusters and only 6 (30\%) said they had lacked practice in pronouncing English final consonant clusters. As many as 12 (60\%) of the respondents said they strongly agreed, 7 (35\%) agreed and only 1 person (5\%) did not agree that the English phonetics and phonemics course helped him in pronouncing the consonant cluster. Even though respondents from semester 6 had taken the English Phonetics and Phonemics course, 10 people (50\%) said that the pronunciation of consonant clusters was still a bit difficult, $9(45 \%)$ were somewhat confident and $8(40 \%)$ said they were confident in their pronunciation. The distribution of errors in pronunciation of the English final consonant clusters can be seen in the graph below.

ERRORS IN PRONOUNCINGTHEENGLISH FINAL CONSONANT CLUSTERS BY ST UDENTSOF THE ENGLISH DEPARTMENT, FACULTY OF HUMANITIES, UDAYANAUNIVERSITY

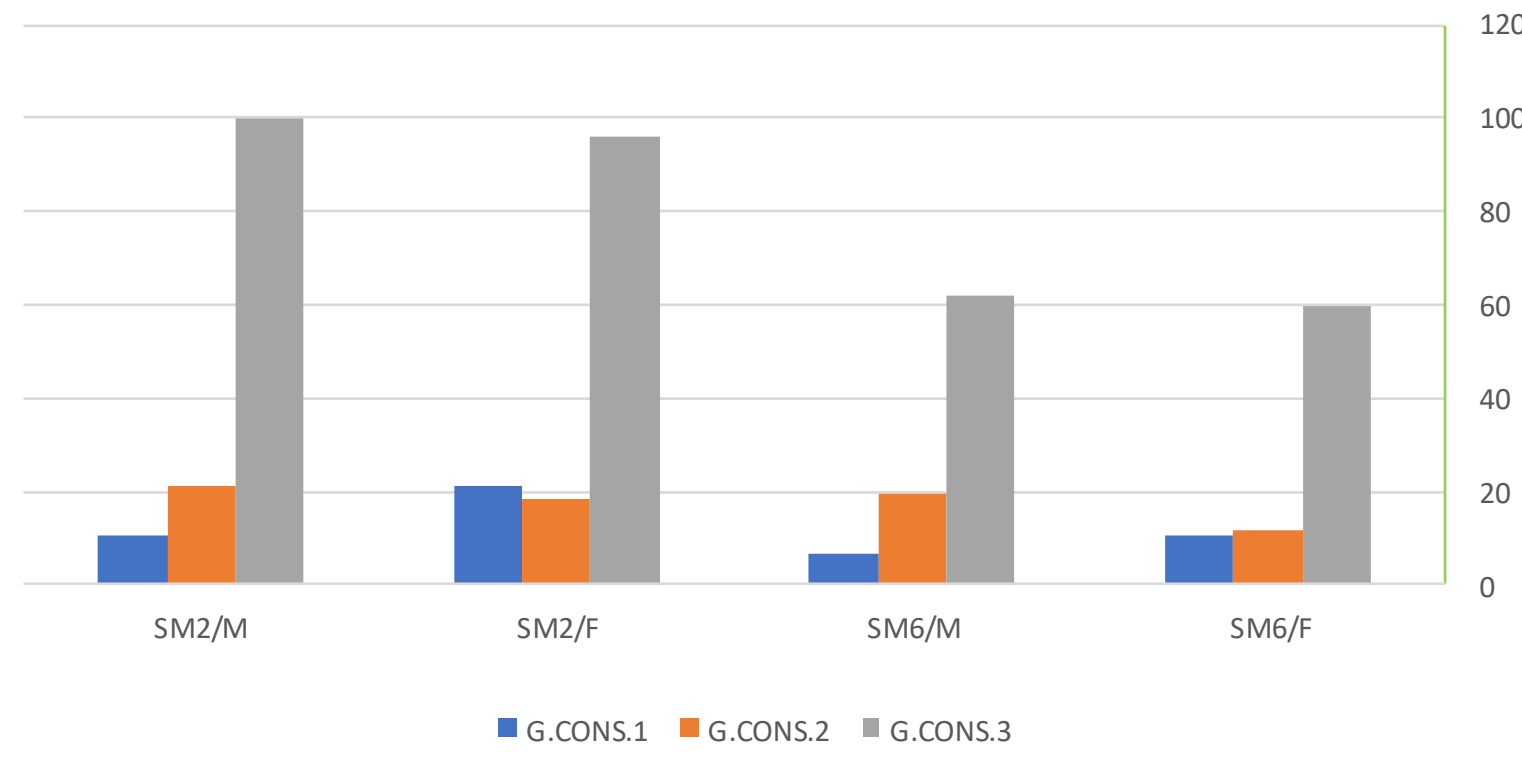

Abbreviation:

$\mathrm{SM} 2 / \mathrm{M}=$ Second Semester Student

G.CONS.1= group 1 . consonant cluster

$\mathrm{SM} 2 / \mathrm{F}=$ Second Semester Student

G.CONS.2 = group 2 . consonant cluster

SM6/M= Sixth Semester Student

G.CONS.3 = group 3 . consonant cluster

SM6/F= Sixth Semester Student

The graph above shows that the English Department students still have problems in pronouncing the English final consonant clusters, the biggest errors made by the students were in pronouncing the consonant clusters in group 3, this is due to the difference between the sound system in English and in the students' mother tongue. However, more errors made by the second semester students compared to the sixth semester students, this proved that the English phonetics and phonemics course given in the fifth semester helped students in improving their pronunciation of the final consonant clusters in English, although more practices should be given to the students. 


\section{International Journal of Current Science Research and Review}

ISSN: 2581-8341

Volume 04 Issue 11 November 2021

DOI: 10.47191/ijcsrr/V4-i11-05, Impact Factor: 5.825

IJCSRR@ 2021

Www.ijcsrr.org

\section{CONCLUSIONS}

From the discussion on the pronunciation ability of English final consonant clusters by the English Department students, the Faculty of Humanities, Udayana University, it can be concluded as follows:

The average score for the pronunciation of English final consonant clusters by the second semester students is quite high, namely 72.90, there are still English final consonant clusters that are difficult for some respondents to pronounce.

The ability to pronounce English final consonant clusters by the sixth semester students could be categorized as high, namely 80.80 , though students in this semester still have problems especially in pronouncing the final consonant clusters in group 3 , but their achievements were higher than the second students' achievements.

The English phonetics and phonemics courses play a very important role in improving students' English final consonant cluster pronunciation, this was evidenced by the significant difference in the average scores of the two groups of respondents, and the results of the questionnaire from the group that had taken this course, 13 respondents (semester six) said strongly agree that they were assisted in the pronunciation of the English final consonant clusters from the understanding and exercises given in this course.

\section{REFERENCES}

1. Gilakjani, Abbas Pourhosein 2016, International Journal of Research in English Education: English Pronunciation Instruction: A Literature Review. Online Published: November 18, 2016

2. Handayani Fitri 2017. Journal of English and Education: Teaching English Pronunciation UsingFilm: October2, 2017, pp.194201.URL:http://ejournal.upi.edu/index.php/L/article/view/10198

3. Katamba, Francis. 1989. An Introduction to Phonology. London: Longman

4. Nafisah Endahati. 2014. Peningkatan Kemampuan Pronunciation Mahasiswa Kelas A1 Semester I Program Studi Pendidikan Bahasa Inggris FKIP UPY TA 2013/2014 Melalui Pendekatan Audiolingual. Yogyakarta: Universitas PGRI

5. Roach, Peter. 2000. English Phonetics and Phonology: A Practical Course. Cambridge: Cambridge University Press.

6. Sari Faizah. 2011. A Practical Guide to Understanding Basic English Phonetics and Phonology. Jakarta: Native Indonesia Press.

7. Vančová, Hana. 2019. Journal of Language and Cultural Education: Current Issues in Pronunciation Teaching to Non- Native Learners of English. Slovakia: Tranava University

8. Yates, L, \& Zielinski, B. 2009. Give It a Go: Teaching Pronunciation to Adults. Sydney, Australia: AMEPRC. Available: http://www.ameprc.mq.edu.au/resources/classroom_resources/give_it_a_go

Cite this Article: Ni Luh Ketut Mas Indrawati, Ida Ayu Made Puspani (2021). The Capability in Pronouncing the English Final Consonant Clusters by the English Department Students, Faculty of Humanities, Udayana University. International Journal of Current Science Research and Review, 4(11), 1504-1513 